ISSN 1392-3196 / e-ISSN 2335-8947

Zemdirbyste-Agriculture, vol. 108, No. 4 (2021), p. 363-370

DOI 10.13080/z-a.2021.108.046

\title{
Candidate-gene expression patterns in diploid and tetraploid Lolium multiflorum spp. multiflorum cultivars under water deficit
}

\author{
Olakunle Kelvin AKINROLUYO, Vilma KEMEŠYTĖ, Kristina JAŠKŪNĖ, \\ Gražina STATKEVIČIŪTÉ
}

\author{
Lithuanian Research Centre for Agriculture and Forestry, Institute of Agriculture \\ Instituto 1, Akademija, Kèdainiai distr., Lithuania \\ E-mail: grazina.statkeviciute@lammc.lt
}

\begin{abstract}
Drought is a critical abiotic stress that disrupts redox homeostasis and is detrimental to plant development. To respond to drought, plants have developed complex mechanisms that allow them to perceive and counter abiotic stresses rapidly. Polyploidy gives rise to many gene expression changes allowing plants to adapt to a broader ecological range. The present study was designed to compare the expression of drought-related genes in diploid cultivars and induced tetraploid lines of Westerwolths ryegrass (Lolium multiflorum ssp. multiflorum). Plants were grown for three weeks in the growth chambers and were subjected to 5 days of water deficit. The relative expression of candidate genes was checked at three-time points, and the relative water content (RWC) was also calculated. The results of the experiment showed critical differences in response to water deficit periods between the diploid cultivars and their respective induced tetraploid lines. The induced tetraploid lines showed a significantly higher expression of drought-related genes than their diploid parents and had higher RWC. Also, out of the genes investigated, dehydrin is the most responsive gene to water deficit periods in Westerwolths ryegrass. Understanding the differential expression pattern of genes involved in drought response provides insight into how cytotypes respond to water deficit periods.
\end{abstract}

Key words: antioxidant defence systems, catalase, dehydrin, polyploids, Westerwolths ryegrass.

\section{Introduction}

Westerwolths ryegrass (Lolium multiflorum ssp. multiflorum) is an important forage grass that is highly digestible by animals. The leaves are rich in minerals and vitamins, which makes them a good substitute to perennial ryegrass (Lolium perenne L.). They set seed in the year, in which they are sown, and can provide high yield during the first cut, serve as an efficient catch crop and prevent soil erosion (Humphreys et al., 2010). They occur naturally as diploids $(2 \mathrm{n}=2 \mathrm{x}=14)$.

Polyploid cultivars of the genus Lolium have been a vital forage grass widely cultivated in Europe. The tetraploid cultivars have superior qualities such as higher water and soluble carbohydrate content, drought tolerance, rust resistance and palatability than their corresponding diploid counterparts (Nair, 2004). Polyploidy can increase genome flexibility making them adapt to a broader ecological region (Blanc, Wolfe 2004; Parisod et al., 2010). Polyploidization entails functional changes without changes in the nucleotide sequence. It also induces a lot of epigenetic modifications such as histone modifications, DNA methylation and chromatin remodelling.

Studies on crops and native species have shown that chromosome doubling often leads to the acquisition of novel traits such as an increase in size, physiological changes and changes in gene expression (Dar et al., 2013). However, these changes are not consistent with adaptive benefits (Paterson, 2005). Generally, polyploids have an increased tolerance to abiotic and biotic stress. This advantage could be the result of higher chromosome copy number and a different pattern in gene expression, which often result in increased protein synthesis or secondary metabolite production (te Beest et al., 2012). Conversely, some studies have reported that some diploid plants are better adapted to abiotic stress (frost) than their tetraploid counterparts making them thrive better in certain climatic conditions (Helgadóttir et al., 2018), and in other cases the differences observed in both cytotypes are small (Kemesyte et al., 2017).

The most crucial factor in crop productivity is water availability; it is the major yield-limiting

Please use the following format when citing the article:

Akinroluyo O. K., Kemešytè V., Jaškūnè K., Statkevičiūtė G. 2021. Candidate-gene expression patterns in diploid and tetraploid Lolium multiflorum spp. multiflorum cultivars under water deficit. Zemdirbyste-Agriculture, 108 (4): 363-370. DOI 10.13080/z-a.2021.108.046 
factor of crop plants. Drought negatively impacts plant development, growth and fertility. Climatic models predict that the severity of the drought is likely to increase in some regions in the future, and this poses a considerable concern for plant breeders (Dai, 2013). Plants have developed several mechanisms to reduce damage arising during drought. These mechanisms include structural changes, physiological and biochemical changes as well as changes in the expression of drought-related genes. Some of the morphological changes include a reduction in the leaf area, efficient root system, reduced stem length and wax content. Also, some of the physiological and biochemical changes involve osmotic adjustments, wateruse efficiency and accumulation of organic and inorganic substances (Blum, Tuberosa, 2018). At the molecular level, response to drought consists of the activation or repression of drought-related genes.

Plant response to drought at the molecular level within and at different ploidy levels has been studied extensively in Arabidopsis thaliana (Seki et al., 2002) as well as in other plant species (Rao et al., 2020). The differential expression of genes coding for functional proteins such as water channel proteins, proteases, late embryogenesis abundant proteins and enzymes involved in the biosynthesis of osmolytes has been studied in water deficit experiments at different time-points and correlated to drought tolerance. There are studies on regulatory gene products such as enzymes catalysing the synthesis of abscisic acid, protein kinase and transcription factors associated with drought tolerance (Yoshida et al., 2015).

Many studies on drought tolerance have been carried out on perennial ryegrass (Jonavičienè et al., 2014; Bothe et al., 2018; Yates et al., 2019; Jaškūnė et al., 2020). However, relatively few studies (Akinroluyo et al., 2020) have been done with Westerwolths ryegrass let alone comparing the gene expression pattern between diploids and the induced tetraploid lines.

The aim of this study was to evaluate the gene expression pattern of functional proteins under water deficit in the diploid and induced tetraploid plants of Lolium multiflorum ssp. multiflorum.

\section{Materials and methods}

Plant material and water deficit treatment. Two diploid Westerwolths ryegrass (Lolium multiflorum ssp. multiflorum) cultivars: Danish 'Magloire' (M2x) and Lithuanian 'Varpe''(V2x), and two autotetraploid lines induced from these cultivars (M4x and V4x), were used in the experiment. Tetraploids were induced from the diploid cultivars with colchicine using the method described in Akinroluyo et al. (2018). Seeds from the third generation of induced tetraploid plants were used and plant ploidy level was confirmed at each generation with the flow cytometer (Partec GmbH, Germany) according to manufacturer's instructions. The experiment was performed in 2019 in Laboratory of Genetics and Physiology, Institute of Agriculture, Lithuanian Research Centre for Agriculture and Forestry.

Sandy soil (350 g) was added to round plastic pots perforated at the base (diameter $\times$ height: $9 \times 8 \mathrm{~cm}$ ). An equal volume $(100 \mathrm{ml})$ of water was added to each pot and allowed to drain. The weight of the soil and water was recorded daily for one week. It was done to ensure the rate, at which water is lost from the pots is relatively constant.

Seeds from diploid Westerwolths ryegrass cultivars of 'Magloire' and 'Varpè' and their respective induced tetraploid lines were germinated on filter paper, and seedlings were transferred to the pots containing $350 \mathrm{~g}$ of sandy soil. Four plants per pot and 48 pots per diploid/ induced tetraploid line were used in this experiment. The pots were placed at random in the climate chamber with a $16 / 8 \mathrm{~h}$ photoperiod and day/night temperatures of $24 / 18^{\circ} \mathrm{C}$ and $60 \%$ relative humidity. The seedlings were grown for three weeks; $100 \mathrm{ml}$ of water was added to the pots daily. For the control group, watering was applied throughout the duration of the experiment. In the stressed group, the water deficit period was commenced by withholding water entirely from the plants. To simulate severe drought, water was withheld entirely from the plants for two weeks. The survival percentage was determined two weeks after rehydration.

Relative water content (RWC). The leaf RWC of stressed and controlled plants was determined 5 days after water withholding using the method described by Smart and Bingham (1974). To obtain the fresh weight (FW), fresh leaves from diploid cultivars and the respective induced tetraploid lines were collected and weighed. The leaves were immediately transferred to plastic sacs containing distilled water. The turgid weight (TW) was obtained by weighing the leaves after saturation for $6 \mathrm{~h}$. The dry weight (DW) was obtained by weighing after drying the leaves in an oven at $70^{\circ} \mathrm{C}$ temperature for $72 \mathrm{~h}$.

RNA isolation, cDNA synthesis and real timepolymerase chain reaction (RT-PCR). For this experiment, 8 candidate genes were chosen: dehydrin (Dh3), copper/ zinc superoxide dismutase $(\mathrm{Cu} / \mathrm{Zn} S O D)$, glutathione peroxidase $(G P X)$, catalase $(C A T)$, guaiacol peroxidase $(P O D)$, ubiquitin-like post-translational modifier $(H U B 1)$, pyrroline-5-carboxylate reductase (P5CR) and ascorbate peroxidase $(A P X)$, based on their role in drought response in other plant species (Bian, Jiang, 2009; Foito et al., 2009; Liu, Jiang, 2010; Li et al., 2015; Patel et al., 2015; Sheikh Mohammadi et al., 2017). For $\triangle \mathrm{CT}$ calculations, reference genes eukaryotic elongation factor 1 alpha (eEF1A), YT521-B-like (YT521-B) and Tat binding protein-1 (TBP-1) were used. Primers for reference genes and candidate genes $\mathrm{Dh} 3, \mathrm{Cu} / \mathrm{Zn} S O D$, $P O D$ and $A P X$ were chosen from the literature, primers for genes $C A T, P 5 C R$ and $H U B 1$ were designed using Primer-BLAST online tool (Ye et al., 2012) based on sequences, available in the NCBI GenBank (Table).

To check for the relative changes in the expression of candidate genes, three-time points were chosen: 1 day after the last watering, 3 days after the previous watering and 5 days after the previous watering. RNA samples were collected from the crown of stressed and controlled plants at every time points. The crown was cut at every time-point and stored in liquid nitrogen before RNA extraction.

GeneJET Plant RNA Purification Kit (Thermo Fisher Scientific, USA) was used to isolate total RNA from leaf tissues of stressed and control plants, following the manufacturer's instruction. Digestion was done with DNase (Thermo Fisher Scientific) to degrade genomic 
Table. Primers for candidate and reference Lolium multiflorum ssp. multiflorum genes selected for RT-PCR

\begin{tabular}{|c|c|c|c|}
\hline Gene & Forward primer $5^{\prime} \rightarrow 3^{\prime}$ & Reverse primer $5^{\prime} \rightarrow 3^{\prime}$ & $\begin{array}{c}\text { Reference / } \\
\text { GenBank ID }\end{array}$ \\
\hline Dh3 & CGGCACCTATGGACAGCA & CCACAGAGGACATGAACCC & Liu, Jiang, 2010 \\
\hline $\mathrm{Cu} / \mathrm{Zn} \mathrm{SOD}$ & ACCACCGTGACAGGAAGC & AACAACATTGATGGGAGCA & Liu, Jiang, 2010 \\
\hline$G P X$ & AAGGCCGAGTATCCGATTT & GCGAGCAGCTTCTTGAGG & Liu, Jiang, 2010 \\
\hline$C A T$ & AGCTCTTCGTGCAGGTCATC & CAGCATCTTGTCGTCGGAGT & JF747381.1 \\
\hline$P O D$ & CTCTACAACGAGACCAACATCAA & GTAGACGTTGTCGAAGGAGTACG & Huang et al., 2014 \\
\hline HUB1 & CCATCGGCGACCTCAAGAAG & GAGGGTGATGTGGTCCTTGTA & KJ782026.1 \\
\hline P5CR & GGCCTTGCATCTCAGACAGT & TATCAGTGTCCCGCGGAATG & KC896628.1 \\
\hline$A P X$ & CCTGAAAGGTCTGGGTTTGA & TCCTTGGCATAAAGGTCCAC & Foito et al., 2009 \\
\hline$T B P$ & TGCTTAGTTCCCCTAAGATAGTGA & CTGAGACCAAACACGATTTCA & Huang et al., 2014 \\
\hline YT521 & TGTAGCTTGATCGCATACCC & ACTCCCTGGTAGCCACCTT & Huang et al., 2014 \\
\hline$e E F 1 A$ & CCGTTTTGTCGAGTTTGGT & AGCAACTGTAACCGAACATAGC & Huang et al., 2014 \\
\hline
\end{tabular}

DNA from the RNA samples. The quality of RNA was checked by running $1 \%$ agarose gel electrophoresis. RNA was quantified before synthesizing the first-strand cDNA with a spectrophotometer NanoDrop 2000 (Thermo Fisher Scientific, USA). Total purified RNA $(1 \mu \mathrm{g})$ was used to synthesize the first-strand cDNA using RevertAid First Strand cDNA Synthesis Kit (Thermo Fisher Scientific) following the manufacturer's protocol. The synthesized cDNA was diluted 15 times with nucleasefree water before RT-PCR analysis. To track the progress of DNA amplification, PowerUp SYBR Green Master Mix (Applied Biosystems, UK) was used in 7500 Fast Real-Time PCR System (Applied Biosystems, USA). The reaction mix for gene expression analysis contained $0.5 \mu \mathrm{M}$ of both the forward and reverse primers, $1 \mu \mathrm{l}$ of $15 x$ diluted cDNA sample and 1x SYBR green master mix, total reaction mixture $10 \mu \mathrm{l}$. The experiment was carried out with three biological replicates and four technical repeats.

Statistical analysis. Experimental results were represented as means \pm standard error (SE). Data were analysed by pairwise test, analysis of variance (ANOVA) with post hoc Duncan multiple range test were calculated using the program $S A S$, version 9.4 (SAS Institute Inc., USA). The gene expression fold change was calculated for each gene/genotype in relation to its well-watered control based on formula $2^{(-\Delta \Delta C)}$.

\section{Results}

Relative water content (RWC) and severe drought. After 5 days of water withholding, the induced tetraploid lines had significantly higher $(P \leq 0.05)$ RWC than their diploid progenitors; V2x had the least leaf RWC. There were no differences in RWC between diploids and tetraploids in the control group (Figure 1).

In the severe drought experiment, water was withheld entirely for two weeks. Extensive wilting was observed in both ploidy levels (visually scored); however, it was more apparent in the diploid cultivars. Recovery from severe drought was significantly faster and higher $(P \leq 0.05)$ in the induced tetraploid lines compared to respective diploid cultivars: their survival rate was 95 $100 \%$, whereas diploid survival rate was $55 \%(\mathrm{~V} 2 \mathrm{x})$ to $75 \%$ (M2x).

Expression of candidate genes. Dehydrin (Dh3). The relative expression of $D h 3$ gene was quantified

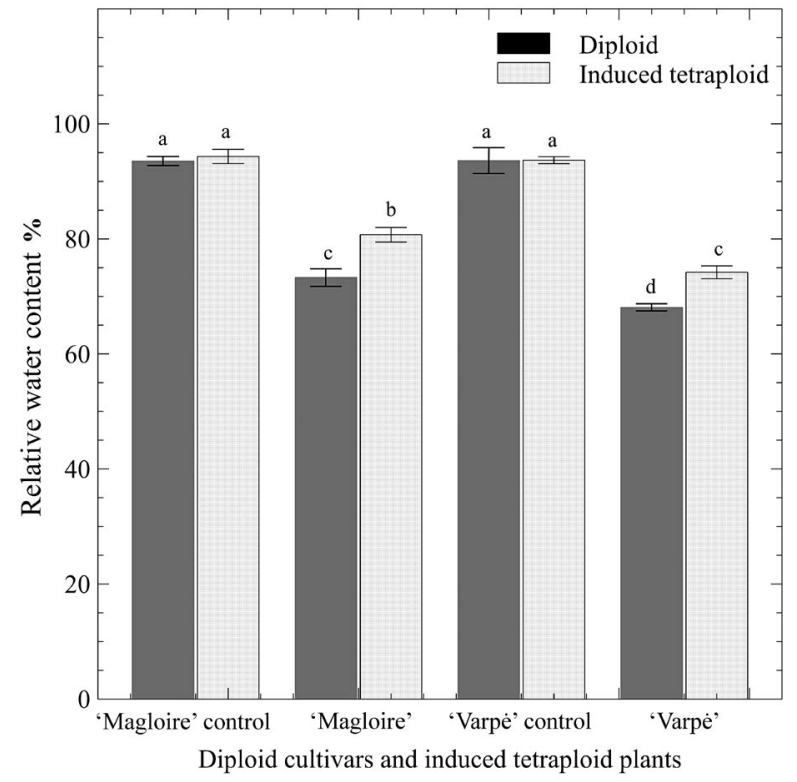

Note. Data shown as mean $\pm \mathrm{SE}$ of three replicates; the means followed by the same letter within each column are not significantly different $(P>0.05)$ according to Duncan's multiple range test.

Figure 1. The relative water content (RWC) of Lolium multiflorum ssp. multiflorum diploid cultivars and induced tetraploid lines subjected to a 5-day water deficit with their respective controls

during progressive water deficit over 5 days (Figure 2). It was observed that the relative expression of $D h 3$ gene was low at the first-time point in all plants. Midpoint during the treatments, a sharp increase in expression of the gene was observed in M4x with a 1405-fold increase, while a 17.5-fold rise was found in M2x (Figure 2A). An increase was also observed in the average expression of Dh3 gene in V4x (104.1) compared with the 60.2-fold increase found in $\mathrm{V} 2 \mathrm{x}$; however, the difference was not significant $(P>0.05)$ (Figure 2B).

The highest expression of Dh3 gene was recorded on the $5^{\text {th }}$ day after water withholding. The diploid cultivar and induced tetraploid lines of 'Magloire' showed higher expression of the gene than in cultivar 'Varpe'. M4x showed significantly higher expression compared to $\mathrm{M} 2 \mathrm{x}(P \leq 0.05)$; V4x also significantly expressed the gene more than V2x. 
A
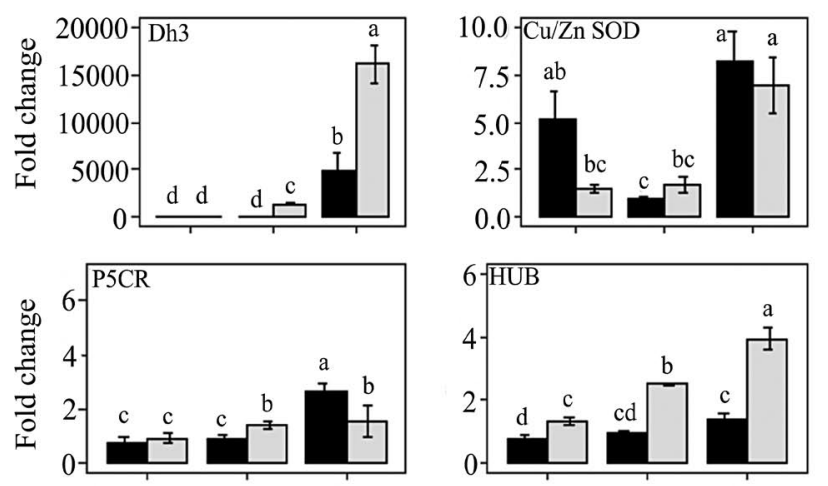

$\mathrm{B}$
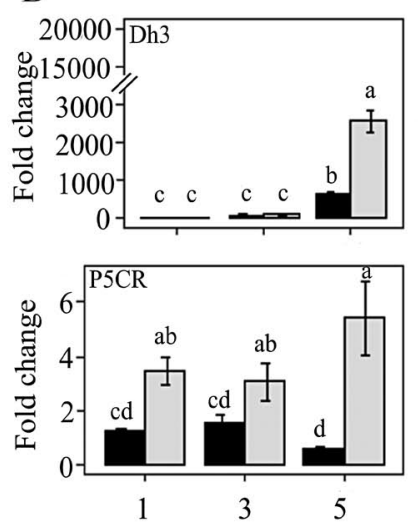

Diploid
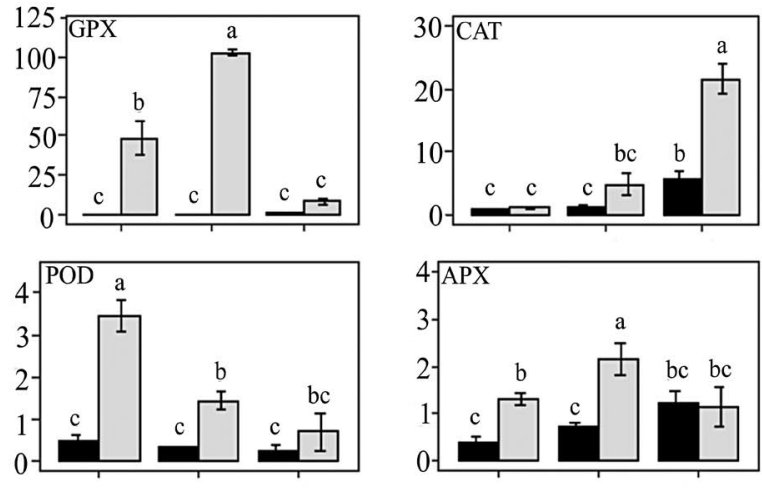
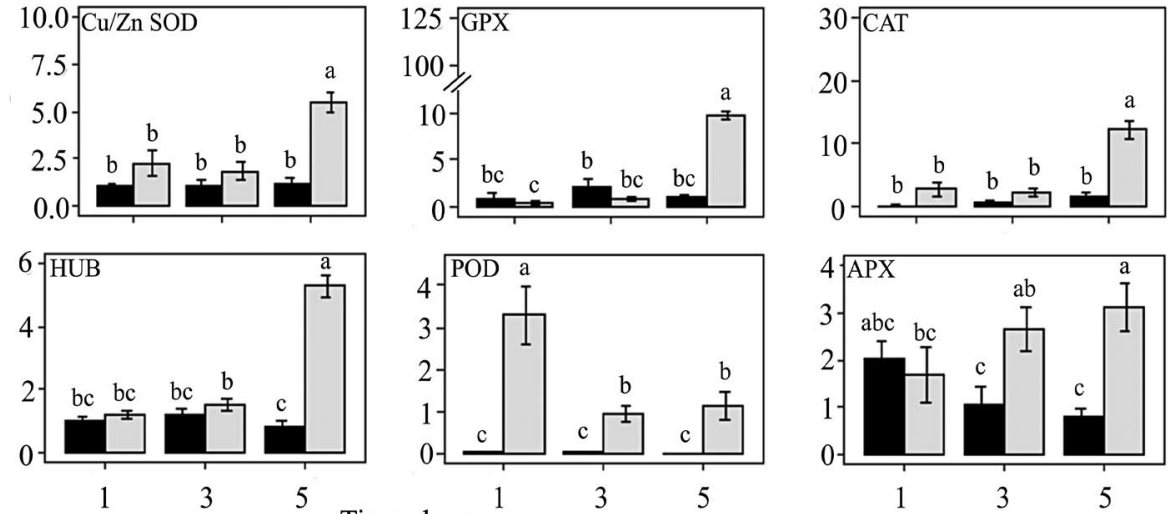

Note. Data shown as mean $\pm \mathrm{SE}$ of four replicates; the means followed by the same letter within diploids and corresponding induced tetraploid lines are not significantly different $(P>0.05)$ according to Duncan's multiple range test.

Figure 2. Candidate gene expression level (fold change) in Lolium multiflorum ssp. multiflorum diploid cultivars 'Magloire' (A) and 'Varpe' (B) and their respective induced tetraploid lines subjected to a 5-day water deficit

Genes involved in antioxidant defence systems.

In response to water deficit periods, an increase in the expression of copper/zinc superoxide dismutase $(\mathrm{Cn} / \mathrm{Zn}$ $S O D$ ) was recorded. Also, variations were observed in the expression pattern of $\mathrm{Cu} / \mathrm{Zn} S O D$ gene from first time-point to the third time-point in cultivar 'Magloire', although no significant difference $(P>0.05)$ was observed at each time-point in the expression level of $\mathrm{M} 2 \mathrm{x}$ and M4x. A significant increase in the expression of $C u / Z n S O D$ gene was recorded in response to water deficit periods between the ploidy levels only at the thirdtime point in $\mathrm{V} 4 \mathrm{x}$, which had a significantly higher final fold-increase in the expression of $\mathrm{Cu} / \mathrm{Zn} S O D$ gene than V2x. The increase in expression pattern in V4x was also progressive (Figure 2B).

Results of the experiment showed an increase in the relative expression of $C A T, P O D, A P X$ and $G P X$ genes in response to water deficit condition. In general, higher expression of these genes demonstrated the induced tetraploid lines than their parental diploid ones. The increase in CAT gene expression followed the same pattern in both cultivars. The difference in CAT gene expression level between the ploidy groups was only significant at the third time-point. The $P O D$ gene expression fold-increase in $\mathrm{M} 4 \mathrm{x}$ was significantly higher than M2x at the first and second time-points, while no significant difference $(P>0.05)$ was observed at the third time-point. However, in V4x, the relative increase in $P O D$ gene expression was significant $(P \leq 0.05)$ at all time-points. $G P X$ gene was relatively highly expressed in induced tetraploid 'Magloire' than its diploid progenitor at the first and second time-points, while no difference in the expression level was observed at the final timepoint. $G P X$ gene was also significantly expressed in induced tetraploid 'Varpe', but only at the final point of the stress.

Ubiquitin-like post-translational modifier (HUB1) and pyrroline-5-carboxylate reductase (P5CR). The expression of P5CR gene was upregulated in response to drought, although variation in the expression level was observed in the diploid cultivars and their respective induced tetraploid lines. Results of our experiment showed the highest expression of $H U B 1$ gene was an approximately $1-2$-fold increase in the diploid cultivars, while a 4-5-fold rise was found in the induced tetraploid lines. The relative changes in $H U B 1$ gene expression were relatively progressive from the first-time point to the third time-point in M4x, while it was constant in M2x. The induced tetraploid lines of 'Varpé' showed the highest expression of the gene at the end of the water stress. 


\section{Discussion}

A source of variation between species within the same or at different ploidy level is the alteration in the pattern of gene expression (Carroll, 2005). Analyses of large-scale microarray studies have confirmed that polyploid plants have a different gene expression pattern, which leads to novel traits (Hegarty et al., 2006). Also, changes in gene expression pattern in synthetic polyploids occur during polyploid formation (Stupar et al., 2007). This experiment focused on the expression pattern of drought related genes in diploid and induced tetraploid L. multiflorum ssp. multiflorum.

Dehydrins are hydrophilic proteins and belong to group II late embryogenesis abundant protein family. The main functions of dehydrins in the cell have been understood to be stabilizing nucleotides and membranes in water deficit conditions, as they serve as molecular chaperones sustaining the necessary activities of functional protein (Graether, Boddington, 2014). Dehydrins have also been recently discovered to have reactive oxygen species (ROS) scavenging properties during stress (Liu et al., 2017; Halder et al., 2018). Some studies have correlated the increase in their synthesis to abiotic stress tolerance (Agarwal et al., 2017).

Results of our experiment showed a progressive increase in the expression of $D h 3$ gene across the treatment period. The induced tetraploid lines expressed the gene significantly more than their diploid parents, and this seems to contribute to higher RWC determined at the end of the experiment. Results of our experiment agree with those obtained by Park et al. (2006), in which they indicated a positive correlation between $D h 3$ and Dh4 genes transcript accumulation and RWC and drought yield index in a set of Korean barley cultivars. Moreover, out of all the genes we investigated, $D h 3$ gene showed the highest fold-increase in response to water deficit condition suggesting that dehydrin might be one of the most important proteins that play essential roles in drought tolerance.

Similarly, Yang et al. (2019) reported that gene coding for dehydrin protein showed the highest expression level using RNA-sequencing, when the drought-resistant potato was treated with polyethylene glycol (PEG). Their result was also validated by quantitative RT-PCR. It is hence becoming evident that expression of dehydrin gene can be used as plant molecular marker for drought tolerance. In our experiment, RWC was used to evaluate physiological drought tolerance, as it is considered a reliable measure of water status in plant tissues. The gene expression pattern in the induced tetraploids as well as higher RWC, and better survival after severe drought, obtained in this experiment, implies that the tetraploids hold great potential for rendering improved stress tolerance.

$H u b 1$ gene encodes for ubiquitin-like protein, which has $35 \%$ amino acid similarity to ubiquitin. It is believed to have an essential role in many developmental processes in plants (Miura, Hasegawa, 2010). Not so many studies have been done on the function of this gene in plants. The only information available on the function of this gene in stressed plants was provided by
Patel et al. (2015). They showed an accumulation of the gene transcript, when perennial ryegrass was subjected to water stress and repression of the gene, when watering was restored, which is an indication that Hubl gene might have a role in drought stress. Results of our experiment showed the highest expression at the third time-point of $\mathrm{Hubl}$ gene was an approximately 1-2-fold increase in the diploid cultivars. In contrast, a 4-5-fold increase was observed in the induced tetraploid lines. The increase in the endogenous transcript of $H u b l$ gene (2-3-folds) during drought periods has been correlated to higher RWC and possibly increased photosynthetic rate in perennial ryegrass plants overexpressing $L p H U B 1$ (Patel et al., 2015). Therefore, the increase in ploidy level impacted the expression of $H u b l$ gene and can be said to contribute to observed higher RWC.

Many studies have shown that the enhanced expression of genes involved in ROS scavenging contributes to drought tolerance in plant species (Laxa et al., 2019). The upregulation of enzymes involved in antioxidant defence is a vital process in acclimation to oxidative stress as well as an essential marker for drought stress. Studies have shown that superoxide dismutase (SOD) is involved in the first response to excessive ROS production by facilitating the dismutation of ${ }^{1} \mathrm{O}_{2}$ radicals to hydrogen peroxide and molecular oxygen (Gill et al., 2015). The conversion of excessive toxic hydrogen peroxide to water and oxygen in the enzymatic pathway is catalysed by CAT, APX, POD and GPX. The difference in gene expression level of these genes in the current experiment is believed to contribute to the higher RWC observed in the induced tetraploid lines compared to their respective parental diploids. Variation in the expression pattern was also observed between the diploid cultivars and the induced tetraploid lines of 'Magloire' and 'Varpe'. GPX and CAT genes showed the highest relative expression level. The expression of GPX gene was higher in the induced tetraploid lines than in their diploid parents, although there were genotypic variations between the induced tetraploid lines. This agrees with the study by Liu and Jiang (2010), in which they indicated that the expression of GPX gene was upregulated in the drought-tolerant perennial ryegrass lines under drought stress but had few or no changes in the susceptible lines. Hence, the expression of GPX is among the most critical genes modulating the physiological response to drought in perennial ryegrass.

Two enzymes: $\Delta 1$-pyrroline-5-carboxylate synthetase (P5CS) and $\Delta 1$-pyrroline-5-carboxylate reductase (P5CR), are the major enzymes involved in the biosynthesis of proline in plants. Studies have shown that P5CS catalyses the rate-limiting step in proline biosynthesis in potatoes or Arabidopsis and are induced during abiotic stress (Su et al., 2011). They also indicated that upregulation in the expression of P5CR gene does not impact the proline content. Conversely, other studies have reported that an increase in the expression of $P 5 C R$ gene caused an increase in the proline content in soybean, which implies that P5CR protein function in various plants could be species- and stress-specific (De Ronde et al., 2004). In perennial ryegrass, a change in the expression of P5CR gene appears to play a central role 
in proline metabolism during abiotic stress. Cytoplasmic P5CR protein, which is encoded by LpP5CR gene, plays a vital role in response to abiotic stress (AbdElgawad et al., 2015). In our experiment, the expression of P5CR gene was upregulated notably in the induced tetraploid line 'Varpe' more than its diploid parent only at the third time-point. Conversely, the diploid cultivar 'Magloire' showed higher expression than the induced tetraploid lines, but only at the first time-point. P5CR gene was upregulated in response to water deficit condition, but the genotypic variation observed makes the role of this gene unclear in L. multiflorum ssp. multiflorum.

To conclude, comparing the induced tetraploid lines to their respective parental diploid ones gave a unique opportunity to purposefully evaluate the influence of ploidy on drought-related gene expression response to water deficit periods avoiding discrepancies relating to different genetic backgrounds. To understand how polyploidy enhances plant productivity in stressful environments is of immense practical as well as theoretical significance. The result of the expression pattern in diploids and induced tetraploid lines may provide further insight into the molecular mechanisms of drought tolerance in L. multiflorum ssp. multiflorum.

\section{Conclusion}

The present study showed that drought stress induced differential responses in diploid and tetraploid lines of Lolium multiflorum ssp. multiflorum. The tetraploid plants demonstrated higher relative water content after a 5-day period of drought treatment as well as higher survival rate after prolonged drought compared to the diploid plants. The expression pattern of drought related genes differed between the diploid cultivars and induced tetraploid lines as well: the induced tetraploid lines showed higher expression level genes encoding for functional proteins. The highest expression increase under drought stress was recorded for $D h 3$ gene, confirming its role in plant drought response.

\section{Acknowledgements}

This study was part of the project funded by the Research Council of Lithuania (grant No. S-MIP-17-24, GrowGene), and the long-term research program "Genetic and purposeful change of agricultural and forest plants" implemented by the Institute of Agriculture, Lithuanian Research Centre for Agriculture and Forestry.

Received 24052021

Accepted 27082021

\section{References}

AbdElgawad H., De Vos D., Zinta G., Domagalska M. A., Beemster G. T. S., Asard H. 2015. Grassland species differentially regulate proline concentrations under future climate conditions: an integrated biochemical and modelling approach. New Phytologist, 208 (2): 354-369.

https://doi.org/10.1111/nph.13481
Agarwal T., Upadhyaya G., Halder T., Mukherjee A., Majumder A., Ray S. 2017. Different dehydrins perform separate functions in Physcomitrella patens. Planta, 245 (1): 101-118. https://doi.org/10.1007/s00425-016-2596-1

Akinroluyo O., Statkevičiūtė G., Kemešytė V. 2018. Tetraploid induction in Lolium multiflorum. Brazauskas G. et al. (eds). Breeding grasses and protein crops in the era of genomics. Springer, p. 73-77.

https://doi.org/10.1007/978-3-319-89578-9_13

Akinroluyo O. K., Jaškūnė K., Kemešytė V., Statkevičiūtė G. 2020. Drought stress response of Westerwolths ryegrass (Lolium multiflorum ssp. multiflorum) cultivars differing in their ploidy level. Zemdirbyste. 107 (2): 161-170. https://doi.org/10.13080/z-a.2020.107.021

Bian S., Jiang Y. 2009. Reactive oxygen species, antioxidant enzyme activities and gene expression patterns in leaves and roots of Kentucky bluegrass in response to drought stress and recovery. Scientia Horticulturae, 120: 264-270. https://doi.org/10.1016/j.scienta.2008.10.014

Blanc G., Wolfe K. H. 2004. Functional divergence of duplicated genes formed by polyploidy during Arabidopsis evolution. The Plant Cell, 16 (7): 1679-1691. https://doi.org/10.1105/tpc.021410

Blum A., Tuberosa R. 2018. Dehydration survival of crop plants and its measurement. Journal of Experimental Botany, 69 (5): 975-981. https://doi.org/10.1093/jxb/erx445

Bothe A., Westermeier P., Wosnitza A., Willner E., Schum A., Dehmer K. J., Hartmann S. 2018. Drought tolerance in perennial ryegrass (Lolium perenne L.) as assessed by two contrasting phenotyping systems. Journal of Agronomy and Crop Science. 204 (4): 375-389. https://doi.org/10.1111/jac. 12269

Carroll S. B. 2005. Evolution at two levels: on genes and form. PLoS Biology, 3 (7): e245. https://doi.org/10.1371/journal.pbio.0030245

Dai A. 2013. Increasing drought under global warming in observations and models. Nature Climate Change, 3 (1): 52-58. https://doi.org/10.1038/nclimate1633

Dar T. H., Raina S. N., Goel S. 2013. Molecular analysis of genomic changes in synthetic autotetraploid Phlox drummondii Hook. Biological Journal of the Linnean Society, 110 (3): 591-605. https://doi.org/10.1111/bij.12154

De Ronde J. A., Cress W. A., Krüger G. H. J., Strasser R. J., Van Staden J. 2004. Photosynthetic response of transgenic soybean plants, containing an Arabidopsis P5CR gene, during heat and drought stress. Journal of Plant Physiology, 161 (11): 1211-1224. https://doi.org/10.1016/j.jplph.2004.01.014

Foito A., Byrne S. L., Shepherd T., Stewart D., Barth S. 2009. Transcriptional and metabolic profiles of Lolium perenne $\mathrm{L}$. genotypes in response to a PEG-induced water stress. Plant Biotechnology Journal, 7: 719-732. https://doi.org/10.1111/j.1467-7652.2009.00437.x

Gill S. S., Anjum N. A., Gill R., Yadav S., Hasanuzzaman M., Fujita M., Mishra P., Sabat S. C., Tuteja N. 2015. Superoxide dismutase - mentor of abiotic stress tolerance in crop plants. Review article. Environmental Science and Pollution Research. 22: 10375-10394. https://doi.org/10.1007/s11356-015-4532-5

Graether S. P., Boddington K. F. 2014. Disorder and function: a review of the dehydrin protein family. Frontiers in Plant Science, 5: 576. https://doi.org/10.3389/fpls.2014.00576

Halder T., Upadhyaya G., Basak C., Das A., Chakraborty C., Ray S. 2018. Dehydrins impart protection against oxidative stress in transgenic tobacco plants. Frontiers in Plant Science, 9: 136. https://doi.org/10.3389/fpls.2018.00136

Hegarty M. J., Barker G. L., Wilson I. D., Abbott R. J., Edwards K. J., Hiscock S. J. 2006. Transcriptome shock after interspecific hybridization in Senecio is ameliorated by genome duplication. Current Biology, 16 (16): 1652-1659. https://doi.org/10.1016/j.cub.2006.06.071 
Helgadóttir Á., Aavola R., Isolahti M., Marum P., Persson C., Aleliūnas A., Brazauskas G., Krisjánsdóttir T. A., Asp T., Rognli O. A. 2018. Adaptability and phenotypic stability of Lolium perenne L. cultivars of diverse origin grown at the margin of the species distribution. Journal of Agronomy and Crop Science, 204 (5): 493-504. https://doi.org/10.1111/jac.12273

Huang L., Yan H., Jiang X., Yin G., Zhang X., Qi X., Zhang Y., Yan Y., Ma X., Peng Y. 2014. Identification of candidate reference genes in perennial ryegrass for quantitative RTPCR under various abiotic stress conditions. PLoS ONE, 9 (4): e93724. https://doi.org/10.1371/journal.pone.0093724

Humphreys M., Feuerstein U., Vandewalle M., Baert J. 2010. Ryegrasses. Boller B. et al. (eds). Fodder Crops and Amenity Grasses: Handbook of Plant Breeding. Springer, p. 211-260. https://doi.org/10.1007/978-1-4419-0760-8 10

Jaškūnè K., Aleliūnas A., Statkevičiūtė G., Kemešytė V., Studer B., Yates S. 2020. Genome-wide association study to identify candidate loci for biomass formation under water deficit in perennial ryegrass plant material and growth conditions. Frontiers in Plant Science, 11: 570204. https://doi.org/10.3389/fpls.2020.570204

Jonavičienė K., Statkevičiūtė G., Kemešytė V. 2014. Genetic and phenotypic diversity for drought tolerance in perennial ryegrass (Lolium perenne L.). Zemdirbyste-Agriculture, 101 (4): 411-418. https://doi.org/10.13080/z-a.2014.101.052

Kemesyte V., Statkeviciute G., Brazauskas G. 2017. Perennial ryegrass yield performance under abiotic stress. Crop Science, 57 (4): 1935-1940. https://doi.org/10.2135/cropsci2016.10.0864

Laxa M., Liebthal M., Telman W., Chibani K., Dietz K.-J. 2019. The role of the plant antioxidant system in drought tolerance. Review. Antioxidants, 8 (4): 94. https://doi.org/10.3390/antiox8040094

Li C., Shuqiang W., Lei H., Yongqiang Q., Huali Z., Haibo X., Zhenyuan S. 2015. Gene cloning and expression of the pyrroline-5-carboxylate reductase gene of perennial ryegrass (Lolium perenne). Horticultural Plant Journal, 1 (2): 113-120. https://doi.org/10.16420/j.issn.2095-9885.2015-0004

Liu S., Jiang Y. 2010. Identification of differentially expressed genes under drought stress in perennial ryegrass. Physiologia Plantarum, 139 (4): 375-387. https://doi.org/10.1111/j.1399-3054.2010.01374.x

Liu Y., Song Q., Li D., Yang X., Li D. 2017. Multifunctional roles of plant dehydrins in response to environmental stresses. Frontiers in Plant Science, 8: 1018. https://doi.org/10.3389/fpls.2017.01018

Miura K., Hasegawa P. M. 2010. Sumoylation and other ubiquitin-like post-translational modifications in plants. Trends in Cell Biology, 20 (4): 223-232. https://doi.org/10.1016/j.tcb.2010.01.007

Nair R. M. 2004. Developing tetraploid perennial ryegrass (Lolium perenne L.) populations. New Zealand Journal of Agricultural Research, 47: 45-49. https://doi.org/10.1080/00288233.2004.9513569

Parisod C., Holderegger R., Brochmann C. 2010. Evolutionary consequences of autopolyploidy. New Phytologist, 186 (1) 5-17. https://doi.org/10.1111/j.1469-8137.2009.03142.x

Park S.-Y., Noh K. J., Yoo J.-H., Yu J.-W., Lee B.-W, Kim J.-G., Seo H. S., Paek N.-C. 2006. Rapid upregulation of Dehyrin3 and Dehydrin4 in response to dehydration is a characteristic of drought-tolerant genotypes in barley. Journal of Plant Biology, 49: 455-462. https://doi.org/10.1007/BF03031126

Patel M., Milla-Lewis S., Zhang W., Templeton K., Reynolds W. C., Richardson K., Biswas M., Zuleta M. C.,
Dewey R. E., Qu R., Sathish P. 2015. Overexpression of ubiquitin-like $L p H U B 1$ gene confers drought tolerance in perennial ryegrass. Plant Biotechnology Journal, 13 (5): 689-699. https://doi.org/10.1111/pbi.12291

Paterson A. H. 2005. Polyploidy, evolutionary opportunity, and crop adaptation. Genetica, 123: 191-196. https://doi.org/10.1007/s10709-003-2742-0

Rao S., Tian Y., Xia X., Li Y., Chen J. 2020. Chromosome doubling mediates superior drought tolerance in Lycium ruthenicum via abscisic acid signaling. Horticulture Research, 7: 40. https://doi.org/10.1038/s41438-020-0260-1

Seki M., Narusaka M., Ishida J., Nanjo T., Fujita M, Oono Y., Kamiya A., Nakajima M., Enju A., Sakurai T., Satou M., Akiyama K., Taji T., Yamaguchi-Shizonaki K., Carninci P., Kawai J., Hayashizaki Y., Shinozaki K. 2002. Monitoring the expression profiles of 7000 Arabidopsis genes under drought, cold and high-salinity stresses using a full-length cDNA microarray. The Plant Journal, 31 (3): 279-292. https://doi.org/10.1046/j.1365-313X.2002.01359.x

Sheikh Mohammadi M. H., Etemadi N., Arab M. M., Aalifar M., Arab M., Pessarakli M. 2017. Molecular and physiological responses of Iranian perennial ryegrass as affected by trinexapac ethyl, paclobutrazol and abscisic acid under drought stress. Plant Physiology and Biochemistry, 111: 129-143. https://doi.org/10.1016/j.plaphy.2016.11.014

Smart R. E., Bingham G. E. 1974. Rapid estimates of relative water content. Plant Physiology, 53 (2): 258-260. https://doi.org/10.1104/pp.53.2.258

Stupar R. M., Bhaskar P. B., Yandell B. S., Rensink W. A., Hart A. L., Ouyang S., Veilleux R. E., Busse J. S., Erhardt R. J., Buell C. R., Jiang J. 2007. Phenotypic and transcriptomic changes associated with potato autopolyploidization. Genetics, 176 (4): 2055-2067. https://doi.org/10.1534/genetics.107.074286

Su M., Li X.-F., Ma X.-Y., Peng X.-J., Zhao A.-G., Cheng L.-Q., Chen S.-Y., Liu G.-S. 2011. Cloning two P5CS genes from bioenergy sorghum and their expression profiles under abiotic stresses and MeJA treatment. Plant Science, 181 (6): 652-659. https://doi.org/10.1016/j.plantsci.2011.03.002

te Beest M., Le Roux J., Richardson D., Brysting A., Suda J., Kubesová M., Pysek P. 2012. The more the better? The role of polyploidy in facilitating plant invasions. Annals of Botany, 109 (1): 19-45. https://doi.org/10.1093/aob/mcr277

Yang X., Liu J., Xu J., Duan S., Wang Q., Li G., Jin L. 2019. Transcriptome profiling reveals effects of drought stress on gene expression in diploid potato genotype P3-198. International Journal of Molecular Sciences, 20 (4): 852. https://doi.org/10.3390/ijms20040852

Yates S., Jaškūnė K., Liebisch F., Nagelmüller S., Kirchgessner N., Kölliker R., Walter A., Brazauskas G., Studer B. 2019. Phenotyping a dynamic trait: leaf growth of perennial ryegrass under water limiting conditions. Frontiers in Plant Science, 10: 1-9. https://doi.org/10.3389/fpls.2019.00344

Ye J., Coulouris G., Zaretskaya I., Cutcutache I., Rozen S., Madden T. L. 2012. Primer-BLAST: a tool to design target-specific primers for polymerase chain reaction. BMC Bioinformatics, 13: 134. https://doi.org/10.1186/1471-2105-13-134

Yoshida T., Fujita Y., Maruyama K., Mogami J., Todaka D., Shinozaki K., Yamaguchi-Shizonaki K. 2015. Four Arabidopsis AREB/ABF transcription factors function predominantly in gene expression downstream of SnRK2 kinases in abscisic acid signalling in response to osmotic stress. Plant, Cell and Environment, 38 (1): 35-49. https://doi.org/10.1111/pce.12351 


\title{
Lolium multiflorum spp. multiflorum diploidinių ir tetraploidinių veislių kandidatinių genų raiška sausros streso metu
}

\author{
O. K. Akinroluyo, V. Kemešyte, K. Jaškūnè, G. Statkevičiūtė
}

Lietuvos agrarinių ir miškų mokslų centro Žemdirbystès institutas

\begin{abstract}
Santrauka
Sausra yra vienas abiotinių stresų, sutrikdančių laisvųjų radikalų pusiausvyrą ir kartu augalo vystymąsi. Evoliucijos metu augalai išvystė ịvairias strategijas, leidžiančias prisitaikyti prie skirtingų stresinių aplinkos veiksnių. Vienas pagrindinių adaptacinių mechanizmų yra poliploidija. Tyrimo metu siekta ištirti gausiažiedès vienametės svidrès (Lolium multiflorum ssp. multiflorum) atsako ị sausros stresą mechanizmuose dalyvaujančių genų raišką skirtingo ploidiškumo augaluose. Genų raiškos sausros metu tyrimui buvo pasirinktos dvi vienametės svidrès veislès: daniška 'Magloire' ir lietuviška 'Varpè'; iš šių diploidinių veislių indukuotos tetraploidinès jų formos. Penkių dienų sausros streso metu augaluose genų raiškos pokyčiai ir santykinè lapų drègmė buvo tirti trijuose laiko taškuose.

Tyrimo rezultatai parodè, kad indukuotų tetraploidinių linijų genotipų genų raiška ir santykinė lapų drègmė buvo žymiai didesnè nei jų tėvinių diploidinių linijų ir atskleidė didesnị tetraploidų atsparumą laisvụjų radikalų pažaidoms bei geresnę drègmès kontrolę augalo organuose. Iš visų tirtų genų didžiausi raiškos pokyčiai nustatyti Dh3 geno; tai atskleidžia jo ịtaką atsako ị abiotinius stresus mechanizmui ir jo kaip molekulinio žymens potencialą siekiant identifikuoti atsparumą sausrai. Glutationo peroksidazės $(G P X)$, askorbato peroksidazės $(A P X)$, katalazės $(C A T)$ ir gvajakol-peroksidazès $(P O D)$ genų raiška smarkiai padidèjo sausros streso metu ir galimai lèmė didesnę indukuotų tetraploidinių linijų santykinę lapų drègmę. Toks sudėtingas kiekybinis požymis kaip atsparumas sausrai augaluose yra reguliuojamas daugelio genų, taigi, atsako stiprumas ir poveikis fenotipui, tikètina, priklauso nuo bendros genų raiškos pokyčių ir DNR sekos funkcinių pakitimų sąveikos.
\end{abstract}

Reikšminiai žodžiai: gausiažiedė vienametė svidrè, poliploidai, katalazè, dehidrinas, antioksidacinès gynybos sistema. 